\title{
Down in Davenport: The Social Response of Antebellum Elites to Regional Urbanization
}

\author{
TIMOTHY R. MAHONEY
}

BETWEEN 1835 AND 1858 a small group of entrepreneurs, led by town founder Antoine LeClaire, guided Davenport's economic development from a small frontier outpost to a significant regional entrepôt with metropolitan ambitions. ${ }^{1}$ Not surprisingly, this economic elite sought, at the same time, to give their economic status a social dimension. While LeClaire and his associates were establishing their businesses and formulating and achieving their local economic goals, they also worked to define themselves as a distinctive social group and to acquire social control over others in town. After arriving in the early and mid-1830s, they had gradually emerged, through competition, as the relative winners in the local economy. As winners, they were quick to translate their economic power into social leadership: they were "in," others were "out"; they controlled, others followed. Gradually, local society became differentiated into groups performing various functions and differentiated by wealth, occupation, institutional affiliation, experience, and origin. Those who came from similar social environments and who had achieved similar levels of wealth pooled their economic resources through partnerships and joint investment ventures, formed institutions and private clubs, and

1. I described Davenport's early economic development and the elite's economic strategies for controlling it in "Down in Davenport: A Regional Perspective on Antebellum Town Economic Development," Annals of Iowa (Summer 1990), 451-74.

THE ANNALS OF IOWA 50 (Fall 1990). CThe State Historical Society of Iowa, 1990. 
intermarried with each other's families. Through such strategies they began to define themselves as the town's social elite.

Initially, the dynamics of this local process of social development followed the early course of the town's economic development as, first, a local depot and then a market town or subregional central place. Located across the river from Rock Island, Davenport was founded in 1832 by Antoine LeClaire and George Davenport, Sr. It quickly emerged in the next decade as the dominant market town along the Great Bend in the Mississippi River. At first the town remained a simple depot for the sparsely settled hinterland, a stopping-off point for immigrants into Iowa, as well as a steamboat stop along the line between St. Louis and Galena. As more settlers entered the backcountry, however, merchants from New York, Cincinnati, and St. Louis arrived in Davenport to supply them. Within a few years, the sale of farmers' produce into the market at Davenport signaled the town's integration into the regional economy centered at St. Louis, where merchants increasingly bought merchandise, sold produce, and banked. In 1841 Davenport became a supplier of wheat and produce in the regional marketplace. By mid-decade it had become a significant export center for hinterland production, and a few years after that, it achieved self-sufficiency in flour production. As the center of wheat production in the valley moved north into Davenport's immediate hinterland, the town's role in the regional economy began to expand, then change. While towns downriver faced relative declines in the produce trades, activity at Davenport surged from 1851 through 1853 . As it did, merchants and capitalists flooded the town, setting in motion a strong population increase.

Once Davenport merchants had consolidated their local control, they found themselves competing across their hinterlands with merchants and entrepreneurs from other nearby market towns. Members of the burgeoning local elite consequently had to balance local economic actions against the constant need to formulate strategies of action that would maintain, expand, or redefine the town's economic role within the regional system. In particular, as the volume of trade to and from town increased, local merchants became increasingly 
aware of the inefficiencies of the steamboat system and, given their lack of investment in that system, their relative lack of influence in further developing transportation to and from town. Possessing a locational advantage in their trade with Chicago, and suspecting that eastern goods would be cheaper in the Windy City, Davenport's elite quickly abandoned the steamboat system and agreed to contribute to financing the construction of the Rock Island Railroad from Chicago to Davenport.

Soon after the railroad's arrival in 1854, trade shifted to the east, and Davenport, suddenly the railhead of the significant artery of trade, experienced an economic boom. Production and export of wheat and corn soared, land values rose, money in circulation expanded, wealth increased, and the number of travelers and immigrants coming into town increased dramatically. The town's population also rose quickly, reaching fifteen thousand within three years. The town was also flooded with entrepreneurs from Chicago and the East seeking to establish both merchant stores and small industries. As they did, they put the older factories out of business, competed against local merchants, and subsumed local sovereignty to the control of metropolitan managers. A financial crisis ensued, and after the Civil War the railhead functions followed the roads farther west. As a result, Davenport's economy retreated to its local central place function, stripped of its local dynamics of development and compelled simply to respond to metropolitan directives. ${ }^{2}$

This new broader range of economic strategies and actions shifted the pattern and dynamics of social development in town. Rather than focusing entirely on consolidating local power within a known society according to a presumably local process of social development, Davenporters were compelled to interact with a broader range of people from across the region. In some cases these contacts occurred within the town itself through interactions with newcomers who came to Davenport to make a new life. But they also came while visiting friends or

2. Timothy R. Mahoney, River Towns in the Great West: The Structure of Provincial Urbanization in the American Midwest, 1820-1870 (New York, 1990), 246-49; idem, "Down in Davenport," 451-74. 
conducting business throughout the region or through correspondence or the newspapers. Either way, these encounters provided the information that shaped their broader social strategies of action in the larger regional society. On the one hand, as members of Davenport's elite encountered other entrepreneurs and business leaders from around the system, they acquired a better idea of who they were socially within that broader network of relationships and acquaintances. On the other hand, as regional interactions became more important and routine, local elites and other townspeople shifted their social concerns from dealing primarily with each other to dealing with different waves of newcomers or with the townspeople's diverse social responses to regional economic and social developments.

Local social development paralleled the town's economic development. Both were gradually coopted by a discontinuous, externally defined process. Social groups no longer evolved from those present but were assembled layer by layer by groups of newcomers. Each group arrived in connection with some episode of regional interaction and stayed to become a part of town society. But rather than expending the energy necessary to fathom local social reality, newcomers merely set to work within a more general, impersonal framework that served to maintain social order. They took their places amid a variety of subgroups whose attitudes and expectations were affected by different experiences. Local society, then, became a grab bag of groups who arrived at different times and acted according to different experiences, attitudes, and criteria. Rather than evolving out of a known social environment, local social development became more impersonal, more credential-oriented, more diverse, and harder to understand. Townspeople thus became less bound by common cultural ideals or expectations than by common location. Davenport's elite employed various strategies locally to deal with these social developments, but ultimately they were forced to yield control to larger regional forces. $^{3}$

3. In their attempts to understand nineteenth-century American urban society, social and urban historians have largely ignored the evolution of these new regionally oriented local societies and their efforts to create a new lan- 
AT EVERY STAGE in Davenport's development, the merchant and professional elite stood at the center of decision making and action in dealing with the region. In Davenport, as in many other western towns, the members of the elite were generally among the first people to arrive in town. Amid the buoyant first wave of settlement and with limited competition, they became established very quickly. Their initial advantage enabled them to stay ahead of those who continued to arrive year after year. As a result, members of the pre- 1845 cohort of the elite persisted at much higher rates throughout the period than any other group in town. Of the twenty-seven merchants and professionals who were among the first settlers and persisted until 1845, twenty-two were economically or socially associated with Antoine LeClaire. Of those, sixteen increased their wealth by 1850 and four others persisted but had less success (see table 1). Especially favored by success were James Bowling, John M. D. Burrows, Ebenezer Cook, Ambrose C. Fulton, Charles Lesslie, George Davenport, Hiram Price, and James Thorington, as well as LeClaire. Thirteen of the members of this cohort persisted past 1860, some of them amassing impressive fortunes; and those thirteen were one-third of all the merchants and professionals who remained in business from 1856 to 1861. In a town where persistence rates for annual cohorts of arrivals was fifty percent or less per year, these rates indicate significant staying power. Nevertheless, they are not much different than figures for comparable groups of established merchants and professionals elsewhere during the same period. ${ }^{4}$

guage of social order. See Frederic Cople Jaher, The Urban Establishment: Upper Strata in Boston, New York, Charleston, Chicago, and Los Angeles (Urbana, IL, 1982), 5; Eric Monkkonen, America Becomes Urban: The Development of U.S. Towns and Cities, 1790-1980 (Berkeley, CA, 1988), 24-30, 127; Don Harrison Doyle, The Social Order of a Frontier Community: Jacksonville, Illinois, 1825-1870 (Urbana, IL, 1978), 62; Kathleen N. Conzen, “Community Studies, Urban History, and American Local History," in The Past Before Us: Contemporary Historical Writing in the United States, ed. Michael Kammen (Ithaca, NY, 1980); Stuart Blumin, The Emergence of the Middle Class (New York, 1989), 298-310.

4. Davenport Gazette, 1-30 July 1845; Scott County, Iowa, Tax Lists, 1849, $1853,1854,1858,1860$, selected from a complete run of tax lists, State Historical Society of Iowa, Iowa City, Iowa; Doyle, The Social Order of a Frontier Community, 97; Davenport City Directory, 1854, 1855, 1856, 1858. 
TABLE 1

WeAlth OF PRE-1845 COHORT OF Merchants

AND PROFESSIONALS THROUGH 1860,

DAVENPORT, IOWA

\begin{tabular}{|c|c|c|c|c|c|}
\hline Name & 1849 & 1853 & 1854 & 1858 & 1860 \\
\hline James M. Bowling & $\$ 2,350$ & $\$ 5,500$ & $\$ 10,000$ & $\$ 10,465$ & $\$ 9,995$ \\
\hline John M. D. Burrows & - & 21,260 & - & 48,607 & 20,500 \\
\hline Alfred Churchill & 14,320 & 41,891 & - & - & - \\
\hline Cook \& Sargent & 112 & 14,9 & - & 104,823 & 22,550 \\
\hline Ebenezer Cook & 3,393 & 14,258 & 40,440 & 104,099 & 17,040 \\
\hline John P. Cook & 320 & - & - & 44,728 & 18,555 \\
\hline James Dalzell & - & 1,500 & - & 5,300 & 5,700 \\
\hline Geo. L. Davenport, Jr. & 21,594 & 40,440 & 37,750 & 68,985 & 82,935 \\
\hline Duncan C. Eldridge & - & 800 & - & 11,237 & 7,087 \\
\hline Nicholas Fejervary & - & - & - & - & 57,062 \\
\hline Ambrose C. Fulton & 8,653 & 11,608 & 26,250 & 36,530 & - \\
\hline Samuel Hirschl & - & 12,965 & - & 36,130 & 32,690 \\
\hline William Inslee & 3,173 & - & - & 2,145 & - \\
\hline Antoine LeClaire & 32,252 & 116,290 & 262,718 & 251,830 & 198,105 \\
\hline Charles Lesslie & 3,165 & 5,780 & 9,400 & 20,810 & 20,160 \\
\hline Louis A. Macklot & 5,084 & 2,935 & - & 18,960 & 13,590 \\
\hline Gilbert C. R. Mitchell & 4,320 & 25,105 & 76,170 & 98,636 & 112,465 \\
\hline John Owens (farmer) & - & 5,600 & - & - & 10,050 \\
\hline Robert M. Prettyman & 183 & 2,500 & - & - & - \\
\hline Hiram Price & 950 & 11,720 & 16,938 & 39,351 & 11,580 \\
\hline Alfred Sanders & 1,500 & 2,660 & - & - & 7,430 \\
\hline Bezeleel Sanford & - & 5,761 & - & - & - \\
\hline George Sargent & - & - & - & 57,720 & 15,650 \\
\hline James Thorington & 736 & 3,610 & - & - & 5,736 \\
\hline William Van Tuyl & - & - & - & - & - \\
\hline Charles Weston & 4,600 & 7,755 & - & - & - \\
\hline Christopher S. Whisler & 4,500 & 9,250 & 9,500 & - & - \\
\hline Dr. James Witherwax & 1,400 & 8,265 & 21,056 & - & - \\
\hline Mean & 5,927 & 16,191 & 51,023 & 56,492 & 35,204 \\
\hline s.d. & 8,326 & 24,507 & 77,135 & 60,427 & 48,565 \\
\hline
\end{tabular}

SOURCES: Scott County, Iowa, Tax Lists, 1849, 1853, 1854, 1858, 1860, selected from a complete run of lists, State Historical Society of Iowa, Iowa City.

NOTE: All of the above had connections to Antoine LeClaire except Churchill, Fejervary, Hirschl, Whisler, and Witherwax. 
What differentiated this Davenport cohort from those at towns up and down the river was its share of control of town wealth. In Galena, Illinois, the top decile of the elite controlled 42 percent of the town wealth in 1845 and about 54 percent in 1854. By 1860 that figure reached 58 percent but then fell back below fifty percent by 1865 . In Dubuque, Iowa, the top decile of wealth holders controlled similar shares of that town's wealth, 58 percent in 1854, for example. In a less wealthy inland town like Jacksonville, Illinois, the top decile of wealth holders controlled 43 percent in 1849 and 50 percent in 1860 . In contrast, the top decile of wealth holders in Davenport, encompassing about half as many men as in Dubuque and Galena in the 1840 s and 1850 s, controlled 54 percent of the town's wealth in 1845 and more than 66 percent in 1853 . Given the smaller scale of Davenport's economy, and, until about 1856 , its less specialized functions, a difference of about 10 percent in the distribution of town wealth is significant. Davenport's distinctiveness appears even more striking when one takes into account the holdings of the most elite of the town's elite. Just two men-Antoine LeClaire, the original proprietor of the land on which Davenport was built, and George Davenport-controlled 14 percent of the town's wealth in 1849. In 1865 the same percentage of Dubuque's wealth, by contrast, was controlled by the ten richest men in town, having declined, for various reasons, from 16.7 percent in 1860 and 24 percent in 1854 . The ten richest men in Davenport, however, controlled 47 percent of the town's wealth, leaving the other members of the top decile only about 12 percent. Among the towns of the early West, therefore, few seem to have been as skewed in terms of wealth, and as divided between persisters and newcomers, as Davenport, Iowa. ${ }^{5}$

The elite's spatial domination of Main Street reflected their staying power and economic dominance. Six merchants-John Burrows, Charles Lesslie, James Bowling, William Van Tuyl,

5. Timothy R. Mahoney, "Urban History in a Regional Context: River Towns on the Upper Mississippi, 1840-1860," Journal of American History 72 (1985), 329-32; Dubuque County Tax Lists, 1854, 1858, 1865, Loras College, Dubuque, Iowa; Doyle, The Social Order of a Frontier Community, 104, 263; Scott County Tax Lists. 


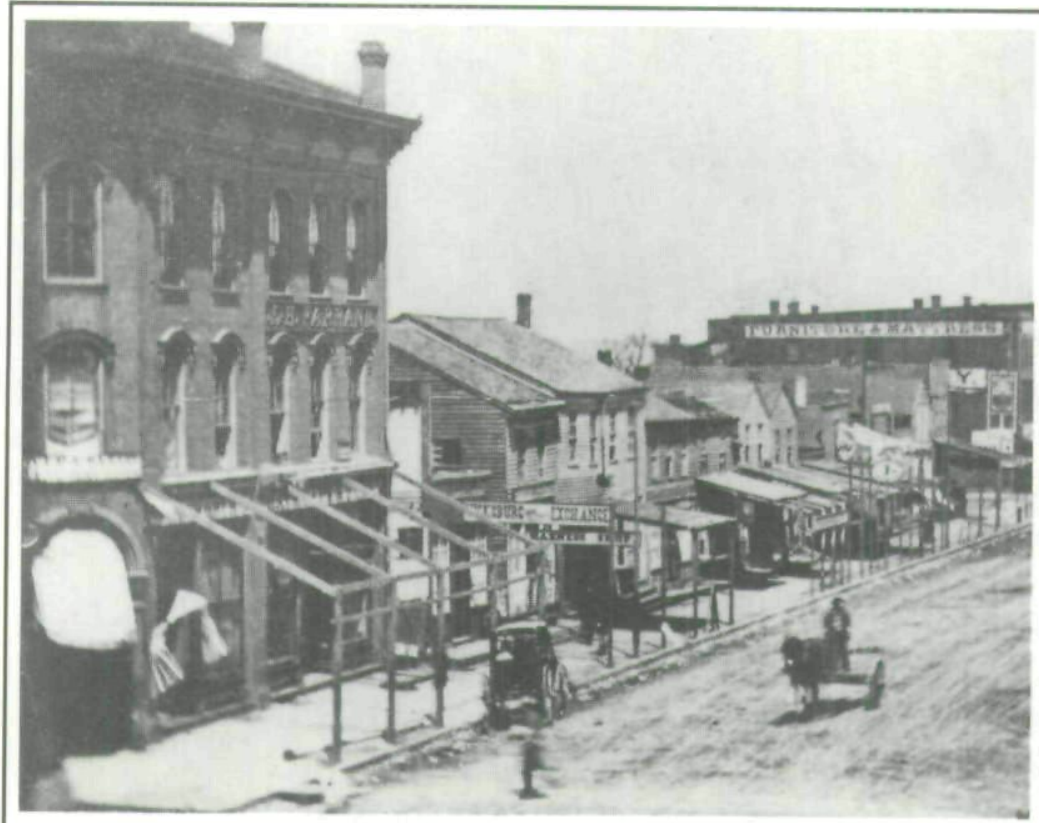

Second Street, north side, between Brady and Perry, looking east, c. 1858. Note the contrast between this block and the photo of LeClaire Row, just one block west, on page 604.

Ebenezer Cook, and Bezaleel Sanford-remained at the same locations downtown throughout the period. As early as 1838 John Burrows's store stood opposite the steamboat landing on the northwest corner of Perry and Front streets. In the next block to the west were the first stores, later enlarged, of Charles Lesslie and John Owens. William Van Tuyl's store, on the corner in between, had already become, by 1845, a "center of attraction" in the business district. Bezaleel Sanford's store was around the corner. Meanwhile, Ebenezer Cook started business in the LeClaire House, then a tourist hotel, on the northeast corner of Main and Second Streets. In 1851, when Antoine LeClaire built a business block along the north side of Second Street east to the northwest corner of Second and Brady, the center of activity shifted to that intersection, at the center of the zig-zag between the wharf and the LeClaire House. Several members of the elite, including William Inslee, relocated in the new brick buildings put up around this corner in the 1852 and 1853 season, thus reasserting their control of the local economy. Much like a large game of musical chairs, 
those who were the first to arrive acquired the best locations and gained most of the business. The capital acquired from their success enabled them, after 1850, to build the finest brick buildings in the business district, further enhancing their visibility and power and securing their position at the center of the local economy. ${ }^{6}$

ANTOINE LECLAIRE'S INPUT accelerated this group's quick emergence and their rapid differentiation in wealth and power from the rest of the town's population of about one thousand people in 1845. As owner of the land on which the town was platted, LeClaire controlled the land market, the primary source of capital in the town's economy. Any remaining unsold land probably belonged to LeClaire, enabling him to control the pace and direction of land development. He built a hotel, a business block, several warehouses on the wharf, and numerous private residences, and he worked tirelessly to encourage church construction. Later, LeClaire offered the lion's share of the donations to encourage the Rock Island Railroad to build its line to Davenport rather than to Burlington or Muscatine. $^{7}$

To acquire a store in a good location, therefore, often necessitated going to LeClaire. His support or lack of support could make or break one's initial efforts. Likewise, LeClaire could provide housing, capital, and credit, all of which enabled one to expand one's business or practice. And, of course, LeClaire, involved with his efforts to build business blocks and housing and provide for construction of churches and schools, could direct business to one's store or practice, providing a critical competitive boost. Whether termed support or control, interaction with LeClaire became a necessity in Davenport.

Ebenezer Cook exemplifies the elite's relationship with LeClaire. For Cook that relationship began the day he arrived in Davenport in 1836. He recalled that day many years later. "I was landed within a few rods of where we now are, and there I found a comfortable log house, the only dwelling near on this

6. Mahoney, River Towns in the Great West, 250-54.

7. Antoine LeClaire Papers, Putnam Museum, Davenport. For a detailed reminiscence about Antoine LeClaire, see Davenport Democrat, 30 August 1880. 


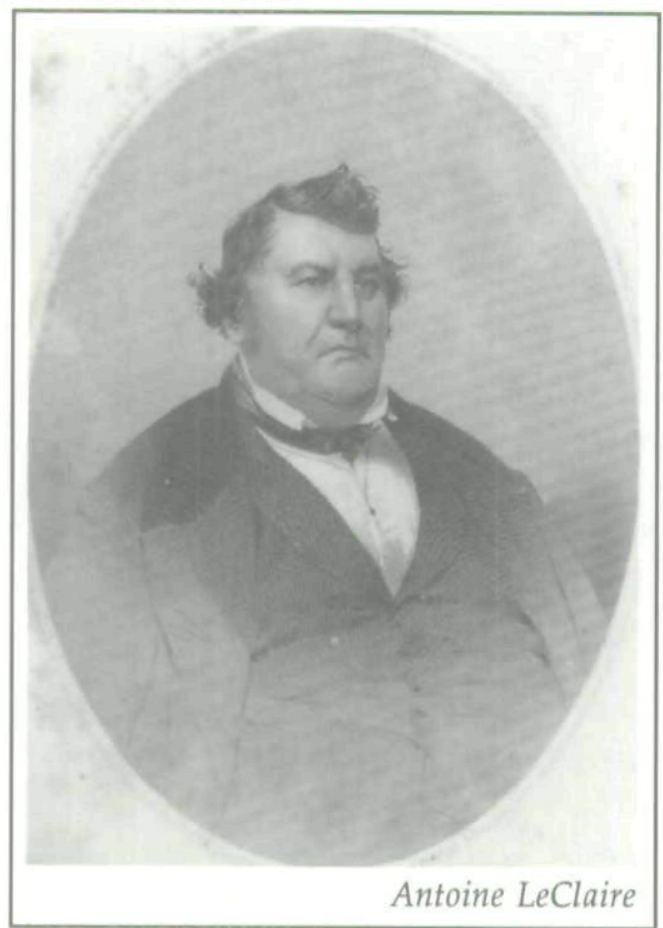

side the river. I made my way to the door, it was opened, and there I found Mr. Le Claire and his worthy wife.... I shall never forget, so long as life remains, the hearty welcome I received; the kind and generous manner in which I was taken care of, during the time I remained with them, while preparing a home for myself." ${ }^{8}$ Apparently LeClaire provided the Cooks with housing and helped them make a large land purchase just outside of town. There, Cook's father and brother started a farm. After Cook was admitted to the bar in 1840, LeClaire became his largest client, providing Cook with extensive practice in land. Soon thereafter, Cook's brother, John, joined the firm and also drew off LeClaire's business to broaden his practice, increase his wealth, and become, in time, a real estate speculator. ${ }^{9}$ Cook joined LeClaire to provide key support when John Burrows launched his mercantile business. In 1841 Burrows

8. Proceedings of the Pioneer Settlers Association of Scott County, Iowa (Davenport, 1858), 31.

9. Obituary for Ebenezer Cook, Davenport Democrat, 7 October 1871; Franc B. Wilkie, Davenport, Past and Present (Davenport, 1858), 104-5; History of Scott County, Iowa (Chicago, 1882), 610, 614-15. 
applied for a contract to supply Forts Crawford and Snelling upriver. When he asked Cook and LeClaire what they thought, they were, as Burrows later noted, "much pleased with my suggestion, and said they would stand by me."10

Others who apparently also had early business or legal dealings with LeClaire included J. W. Parker, John F. Dillon, George B. Sargent, George and Bailey Davenport, Alfred Sanders, John Owens, Gilbert Mitchell, Hiram Price, Ambrose C. Fulton, and Charles E. Putnam; all later became eminent men in the town. As in Cook's case, these initial business contacts led indirectly to other connections, most notably with David A. Burrows, Robert M. Prettyman, D. C. Eldridge, and Charles Lesslie. The surviving scraps of LeClaire's papers only hint at the extent of his economic power and potential control over newcomers, who, in time, became deferential associates and fellow members of a very elite elite. When a Davenport lawyer, in correspondence with others across the region, routinely wrote, as an aside, that "Mr. LeClaire desires me to communicate his respects to you," he unwittingly provided evidence of LeClaire's presence in nearly every aspect of Davenport's business. ${ }^{11}$

In the 1850s LeClaire's contacts became a bit more open. He apparently bankrolled the Cook and Sargent bank through its rapid rise in the early fifties, and then when it got in trouble, he supported the bank with additional loans as long as he could before pulling the plug in late 1859 , as we will see. He also sup-

10. J. M. D. Burrows, "Fifty Years in Iowa," in Milton Milo Quaife, ed., The Early Day of Rock Island and Davenport: The Narratives of J. W. Spencer and J. M. D. Burrows (Chicago, 1942), 163-64.

11. Antoine LeClaire Papers, Putnam Museum, Davenport; J. W. Parker to Thomas McKnight, 14 March 1838, Thomas C. McKnight Papers, State Historical Society of Iowa; History of Scott County, 610, 619, 622, 631, 924; Davenport Democrat, 15 May 1915; Edward H. Stiles, Recollections and Sketches of Notable Lawyers and Public Men of Early Iowa (Des Moines, 1916), 188; Wilkie, Davenport, Past and Present, 104-5; Obituary for Mrs. G. C. R. Mitchell, Davenport Democrat, 24 March 1908; Obituary for Bailey Davenport, Davenport Democrat, 9 February 1890; Obituary for William Inslee, Davenport Democrat, n.d., 1889; Last Will and Testament of Antoine LeClaire, 1861, Office of the County Clerk, Scott County Courthouse, Davenport (in the will LeClaire refers to "my friends [my emphasis] C. E. Putnam, G. C. R. Mitchell, and George Davenport (Jr.)"; Burrows, "Fifty Years," in Quaife, Early Day, 136-37, 150-53. 


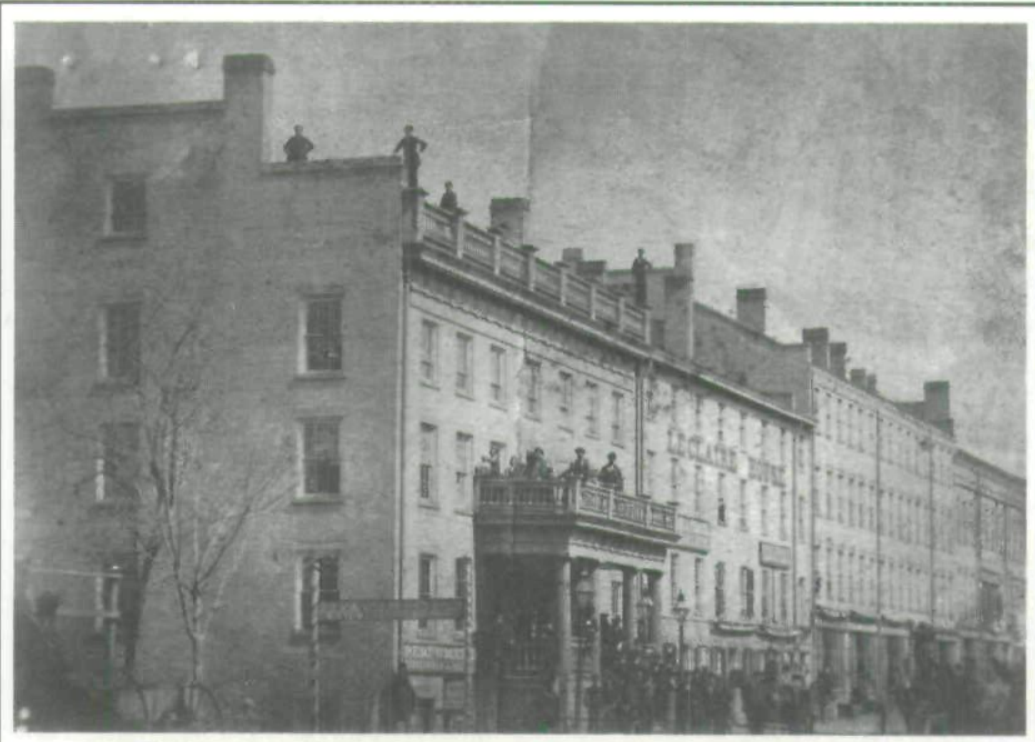

LeClaire Row, including the LeClaire House, looking east along the north side of Second Street between Main and Brady,

c. 1862 .

ported John Burrows's business. On a broader scale he became deeply involved in the scheme to bring a railroad to Davenport, providing property, capital, and, when the railroad needed a depot, even his old house. He was active in business downtown, either competing with some of his associates, serving as their landlord, or providing services he considered necessary to spur economic development. He expanded his real estate business by completing the LeClaire House and running LeClaire Row east along the north side of Second Street by 1853 . He also built the Davenport Hotel on the wharf, the post office block, and several smaller buildings downtown. In 1851 he went into the wholesaling business on the wharf with his partner George Davenport, Jr. (his old partner, George Davenport, Sr., had been murdered in 1845). The same year they built a foundry at Scott Street and the wharf. A year later they opened an iron store across from the LeClaire House on Second Street.

LeClaire also broadened his interest and control to include the working classes by dispensing contracts, demanding services, granting loans, building houses, providing office space, extending credit, and hiring workers. Clearly LeClaire had the power to make or break anyone in town. Thus, doing business 
with him was, in most cases, necessary for persisting successfully in Davenport in the 1840 s and 1850 s. $^{12}$

IN MANY WAYS this group of men who controlled town wealth was similar to most other "core communities" in new towns in the Midwest in the mid-nineteenth century. ${ }^{13}$ Most of the men were in their thirties and forties and hence tended to persist because they had a stake in the town's future. From their initial economic activities, we can follow the careers of several of these men who began as lawyers or merchants and later became bankers, real estate agents, and investors, and, finally, investors in railroads and other public corporations. A few Davenporters of this generation, most notably George B. Sargent, Austin Corbin, and John F. Dillon, even went on from their modest beginnings in Davenport to become lawyers, brokers, and financiers in New York. ${ }^{14}$

Throughout the period there were many economic partnerships among the members of the original cohort of 1845 . In addition to John Burrows, Robert Prettyman, and George Davenport, there were also the notable teams of Louis Macklot and Austin Corbin, Ebenezer Cook and George Sargent (which later involved John Cook), George Davenport and Antoine LeClaire, James Parker and James Thorington, John Owens and William Inslee, and John Dillon and Hiram Price. Among the thirty men in the cohort, there were twenty-seven partnerships during the period. By pooling their wealth, they succeeded in increasing it (see table 1). Consequently, they persisted at a much higher rate than the rest of the population. In time their power enabled them to

12. History of Scott County, 609, 665, 925; Willard Barrows, "History of Scott County, Iowa," Annals of Iowa 1 (1863; reprint, Iowa City, 1964), 58-59, 64, 68, 74-76; Davenport Democrat, 30 August 1880; [H. A. Porter], Rock Island and Its Surroundings in 1853 (Chicago, 1854), 27; Diary of William J. Barney, Dubuque, State Historical Society of Iowa.

13. Kenneth J. Winkle, The Politics of Community: Migration and Politics in Antebellum Ohio (New York, 1988), 109-31.

14. Stiles, Recollection and Sketches, 188; Earle D. Ross, "George Barnard Sargent, Western Promoter," Iowa Journal of History and Politics 45 (1947), 129-30; Obituary for Mrs. George Sargent, Davenport Democrat, 15 March 1896; Burrows, "Fifty Years," in Quaife, Early Day, 252; History of Scott County, 771; John F. Dillon Papers, State Historical Society of Iowa. 
equate their own success with the town's. Thus, they argued effectively that they should be deferred to in matters of governmental policy. Not surprisingly, one of their own was elected mayor every year through $1860 .{ }^{15}$

While pursuing a strategy of establishing themselves as an economic elite, and from that acquiring the power to rule, this group also pursued a policy of solidifying their social position as a group apart from the rest of the population. As persisters, they could achieve much of the social power associated with the establishment and operation of churches and other voluntary institutions. Members of the elite played significant leadership and service roles in a variety of Davenport's religious denominations. The Cook brothers, for example, played a major role in organizing the charity work of the Episcopal church; Duncan C. Eldridge and John Owens were founders of Davenport's Christian church; and Gilbert Mitchell and Antoine LeClaire provided key support for the town's Roman Catholic church. As in other towns, the elite was also well represented in the Old Settlers Society, one of the few more general secular societies in town. ${ }^{16}$

The social solidarity created by participating in common religious groups and voluntary associations became even more critical as the town began to grow rapidly and this small group of elite men found themselves the only socially recognizable people amid a constantly changing population of strangers. In the early fifties waves of newcomers sought to enter the ranks of Davenport's mercantile community. As they did, the size of the cohort of 1845 in relation to the number of newcomers who arrived and stayed for at least a few years decreased precipitously. Although they may have had some viable basis for tight control in a town of fewer than a thousand people (two hundred families) in 1845 , this oligarchy of thirty men found themselves trying to control five thousand people in 1853 and as

15. Iowa credit report ledger, vols. 47,48 , Scott County, Iowa, R. G. Dun and Company Collection, Baker Library, Harvard University Graduate School of Business Administration.

16. For religious denominations of the Davenport elite, see History of Scott County, 732-48; Scott County Iowan 2 (May 1978), 7; "Scott County Iowa Cemetery Records," vol. 1. (Des Moines, n.d.), 65; Proceedings of the Pioneer Settlers Association of Scott County, 14. 
many as fourteen thousand during the boom in 1857. Among merchants and professionals alone, their share dropped from about half in 1845 to about 15 percent in 1855 and to less than 5 percent in $1858 .{ }^{17}$

As more and more people arrived and possibly tried to challenge the elite, the degree of social interaction among them actually increased, and relations became tighter. At least fifteen people among this group were friends or kin, and there were ten marriages among brothers or sisters or children of the group. Indeed, ten of the twenty-one richest men in town were related by marriage or kinship, and eight of the ten richest were connected by marriage, kin, or friendship. In each case, the social cohesiveness of Davenport's elite exceeded that of towns farther east during the same period, perhaps indicating a defensive strategy to set themselves apart from the rest of the townspeople. ${ }^{18}$

That strategy is further suggested by the rapid construction, between 1852 and 1858, of an elite neighborhood northeast of the downtown area. That neighborhood was more than just an area in which people of the same socioeconomic status chose to live. Most of the residents of the forty or so houses in the neighborhood were connected by marriage and business ties, so entrance to one parlor undoubtedly brought indirect though exclusive entrance to numerous others on the hill (see map). ${ }^{19}$

To some this development seemed to isolate members of the elite from the rest of the townspeople. One family moving up the hill found themselves "too far out of town for informal neighborly visits such as [the townspeople] had always delighted to pay, passers-by halting on the way, neighbors 'dropping in.'" George Sargent, housed in one of the hill's most magnificent mansions, made a point of having an annual "open house" to which anyone in town was welcome, but that only

17. Davenport City Directory, 1854, 1855, 1856, 1858.

18. Paul Johnson, A Shopkeeper's Millennium (New York, 1978), 26; Jaher, The Urban Establishment, 1-13, 452-723.

19. Davenport City Directory, 1856, 1858. 


\section{MAP}

The Elite Neighborhood in Davenport, Iowa, in 1858

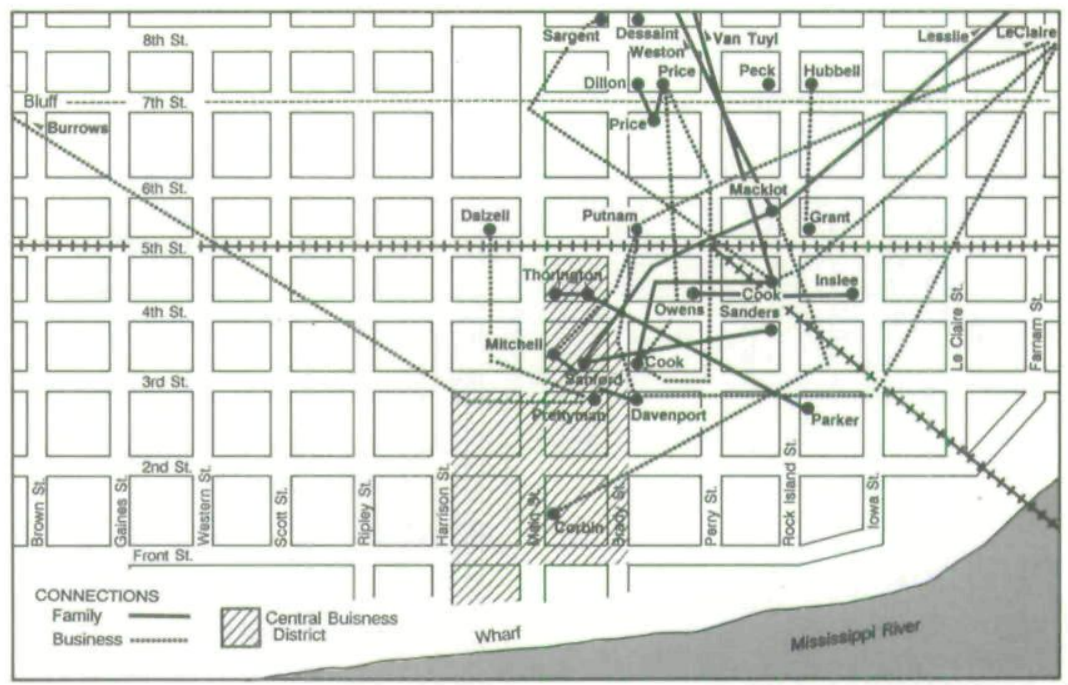

accentuated his desire to be left alone in exclusive society and privacy the rest of the year. ${ }^{20}$

The architecture of the houses, ranging from Greek Revival to classical Italianate style, emerged not from the town's local context, but from the elite's aspirations to build houses that would reflect the lifestyles of elites up and down the river or back east. William Barney's comment on the Macklot house in Davenport was the highest complement he could have paid to a family. "The mansion is admirably built and furnished. I have seen nothing so eastern ... since I left Baltimore." ${ }^{21}$

The local and regional meaning of the neighborhood was not lost on the townspeople. On the one hand, the new houses became symbols of social aloofness. On the other, they

20. Octave Thanet [Alice French], The Man of the Hour (New York, 1905), 33; Obituary for Mrs. George Sargent, Davenport Democrat, 15 March 1896.

21. Loren Nelson Horton, "Town Planning, Growth, and Architecture in Selected Mississippi River Towns of Iowa, 1833-1860" (Ph.D. diss., University of Iowa, 1978), 205-6, 215-38, 259-74, 279-80; Diary of William Barney, 12 April 1846. 


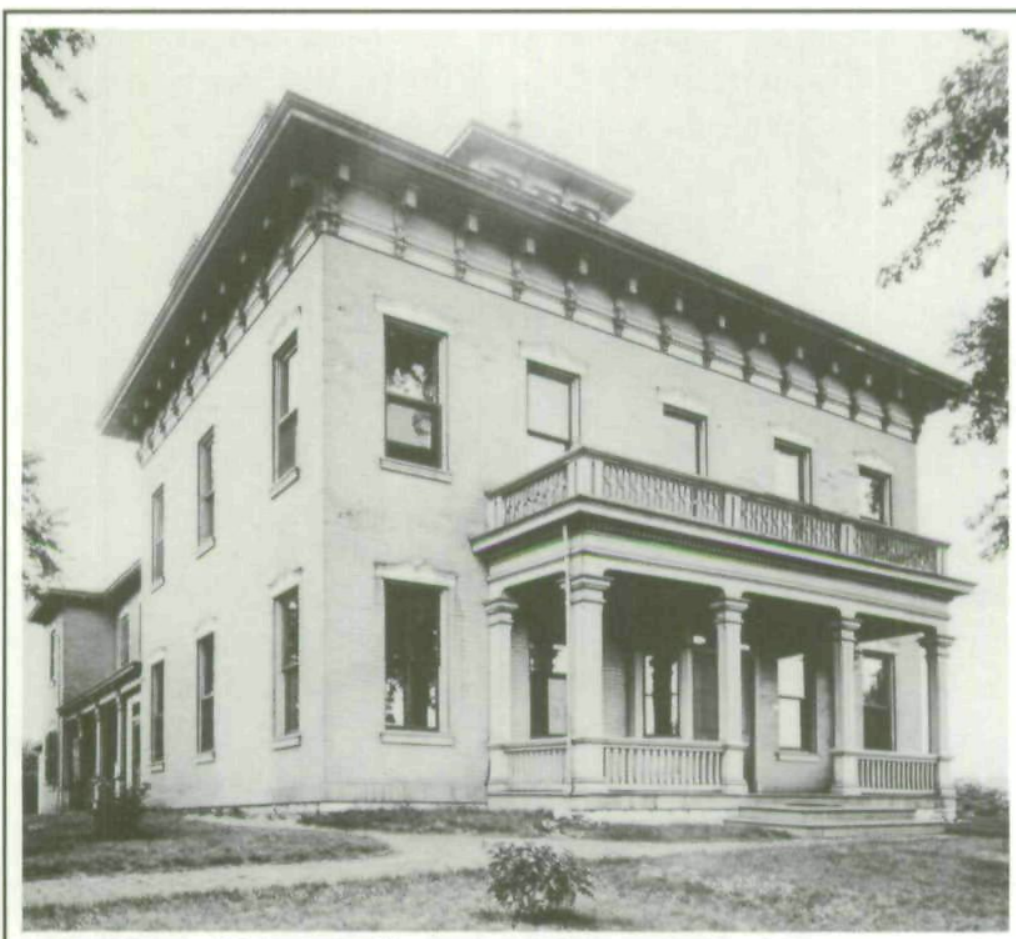

Antoine LeClaire's Italianate mansion, completed in 1856, on the bluff overlooking downtown Davenport and the Mississippi River.

expressed a hierarchy of power in town life. The social meaning that these houses quickly acquired is evident from the actions of the mob that marched up the hill during the June 1859 "currency riot" and confronted the town leaders at the doors of their new houses. Chasing the Cook family out of the front rooms with a few bricks and bottles, the mob then forced Cook to come to the front door to speak to them. Although he did so, he was infuriated at the social affront of challenging him at his house. ${ }^{22}$ If the records existed, which they do not, further social meaning might be inferred from the public separation of the elite neighborhood from the town. The social meaning of building Italianate mansions on the hills above the downtown, the river, and the poorer neighborhood along the river plain could not have been lost on residents of Davenport.

22. Burrows, "Fifty Years," in Quaife, Early Day, 273-75. 
THE SOCIAL STRATEGIES of Davenport's elite reveal much more than the state of the community in Davenport, however. Their actions reflected a broader uncertainty and nervousness about the regional position of the town they had nursed into existence, as well as about their own role in the town and in the region. There was, to be sure, occasional evidence of interclass friction in town: the charity work of Ebenezer Cook and George Sargent and the philanthropy of Antoine LeClaire and John Burrows exemplified one kind of class interaction; the street riots of $1855,1857,1858$, and 1859 revealed others. The primary drama of the $1850 \mathrm{~s}$, however, was the effort to direct the town's energies toward maintaining and expanding its economic function in the region, and to push Davenport to the next level of urban development at the center of a subregional system. Ironically, the deep pockets of the town's elite may have spelled their doom. Confident in their ability to pursue successful economic expansion, and buoyed by speculation that was heating up the local economy, they expanded far too rapidly. Hence their social defensiveness seems even more intriguing, given their blatant excessiveness in expansionary activity between 1852 and 1859.23

It is not clear how quickly locals became aware of these social tensions, but they certainly must have been aware of the wave of people who entered town just before and after the arrival of the railroad. Combined with uncertain changes in the structure and organization of the economy, these newcomers added to the social and economic tension of rapid growth. In 1853 the beginning of the construction of the Missouri and Mississippi Railroad through Davenport drew two or three hundred men to town, accelerating the population increase that had begun with the gradual growth of the economy since 1851. As the Rock Island Railroad approached Davenport from the east, more laborers flooded into town. Still another wave followed in

23. August P. Richter, Geschichte der stadt Davenport und des county Scott (Davenport, 1917), 664-68; Harry E. Downer, History of Davenport and Scott County, Iowa, 2 vols. (Chicago, 1910), 1:985; Burrows, "Fifty Years," in Quaife, Early Day, 273-75; Obituary for Ebenezer Cook, Davenport Democrat, 7 October 1871; Barrows, "History of Scott County," 112; Davenport Democrat, 21 November 1881. 
early 1854 with the beginning of the construction of the great railroad bridge between Rock Island and Davenport. The job sheets have not survived, but the cost of the bridge, estimated at between two hundred fifty and four hundred thousand dollars, suggests that as many as several hundred workers may have been drawn to work temporarily in Davenport. The overall number of laborers in Davenport rose from just over 100 in 1850 to 1,113 in 1856 and 1,380 in 1858, after which the number fell back below 800 . If one includes spouses and families of many of these workers (though many of them were undoubtedly single), the new arrivals must have increased the town's population by at least three or four thousand. ${ }^{24}$

The demand for housing, food, and supplies soared with the population, touching off a boom in the local economy. The number of craftsmen and carpenters working to meet the housing demand increased sevenfold from 1850 to 1856 , when more than half of the seven hundred craftsmen in town were carpenters. As supplies reached town from the north, establishing a lumber trade that would sustain Davenport briefly until after the Civil War, the town was practically built anew. Annual construction of new buildings rose from 300 per year in 1853 and 1854 to 600 in 1855 and more than 1,200 in 1856. In 1857, the boom year, one source reports that as many as 1,300 buildings were put up in town. By 1858, when 1,112 buildings were erected, the town contained 2,375 dwellings and about 2,625 other buildings, or about 5,000 buildings for a population of some 16,000 people. ${ }^{25}$

Assuming that about half the buildings built in any year were dwellings, a comparison of the number built to the estimated annual increase in population reveals that the economy responded to demand better in some years than in others. In

24. Porter, Rock Island and Its Surroundings, 23, 26-27, 32-33; Fourth Annual Review of the Commerce, Railroads, and Manufactures of Chicago, 1855 (Chicago, 1855), 70; Davenport City Directory, 1855, 1856, 1858; Nathan H. Parker, The Iowa Handbook for 1856 (Boston, 1856), 136; Wilkie, Davenport, Past and Present, 122; Barrows, "History of Scott County," 121, 125; Davenport Democrat, 30 August 1880.

25. Downer, History of Davenport and Scott County, 1:194, 195, 197, 198, 200, 208; Barrows, "History of Scott County," 121; Davenport City Directory, 185657, 27; Wilkie, Davenport, Past and Present, 325. 
TABLE 2

POPUlation GROWTH AND Housing CONSTRUCTION, 1854-1858

\begin{tabular}{lcrrrr}
\hline & 1854 & 1855 & 1856 & 1857 & 1858 \\
\hline $\begin{array}{l}\text { Houses Built* } \\
\begin{array}{l}\text { Population Increase } \\
\text { During Year (est.) }\end{array}\end{array}$ & 150 & 300 & 600 & 650 & 550 \\
$\begin{array}{l}\text { Ratio: Population/ } \\
\text { Houses }\end{array}$ & 3.3 & 1,000 & 4,000 & 2,000 & 2,000 \\
\hline
\end{tabular}

SOURCES: See note 25 .

*I have estimated the number of houses built during each year by assuming that about half of the reported buildings constructed were houses.

1856 in particular, and to a lesser extent in 1858 , it must have been very difficult for newcomers to find adequate housing. Many newcomers must have been forced to double and triple up (see table 2). ${ }^{26}$ Yet newcomers continued to arrive in Davenport because rents were generally lower than in other towns in the region, despite later reports that rents soared during 1856 and early 1857. Furthermore, after the crash of 1857 flattened the economies of several towns up and down the river, Davenport, which survived the crash, became a temporary oasis amid depression. Hence, as one observer noted, "A portion of our daily increase of population is made up of mechanics, and others, who cannot go to other places if they so desire." Comparing persistence rates of Davenport's laborers to other towns also indicates that workers coming to Davenport tended to leave less quickly. Thus, these newcomers still must have been able to find work in the expanding local economy. ${ }^{27}$

It appears, then, that Davenport's boom was a bit more controlled than those elsewhere in the West, that town builders were generally able to keep up with housing demand, and thus that the town was able to offer suitable jobs and affordable housing for newcomers. Not until 1858, when the local economy began to slow down, did unemployment begin to rise and the housing shortage deteriorate to the breaking point. Only then did it become apparent that the railroad, which had

26. Downer, History of Davenport and Scott County, 1:197.

27. Wilkie, Davenport, Past and Present, 140, 325. 
seemed like such a certain boon to the town economy, had created unanticipated problems and pressures.

THE ELITE RESPONSE to these economic and social pressures was to seek, on the one hand, to establish and maintain order and control, while on the other hand encouraging destabilizing expansion and development. Efforts by Ebenezer Cook and George Sargent, and later John Burrows, to expand the local economy by issuing vast amounts of local currency illustrate the hazards of this dual response.

Like all western merchants, lawyers, or entrepreneurs turned bankers, Cook and Sargent attempted to provide vital financial services that would facilitate trade, stimulate investment, and create a dynamic local economy. Initially they had been very active in land sales and investment, with branch real estate offices in Dubuque, Rock Island, and Iowa City. They hoped increasing land sales would attract newcomers, increase farming, and stimulate town economic development. In 1847 they focused their efforts by opening a bank and directly involving themselves in stimulating mercantile and industrial activity in Davenport. ${ }^{28}$

Because Iowa law forbade banks to issue currency, Cook and Sargent were initially compelled to generate profits through loans and exchange. At the same time, the capital generated by these loans was essential for the economic and social development of the town's underdeveloped frontier economy. Limited capital placed restraints on both town development and on the bankers' profits. So as both the town and the bank struggled to break free of those restraints, the bankers' selfinterest and the interests of the town merged; stimulating the local economy through loans translated directly into personal profit for the bankers.

The necessary reliance of Davenport's merchants and investors on eastern capital and credit compounded their problems. They were routinely stretched to the limit of their credit and deep in debt. Whatever specie (gold and silver) circulated

28. Burrows, "Fifty Years," in Quaife, Early Day, 220-21; History of Scott County, 114-15; Wilkie, Davenport, Past and Present, 104-5; Robert Swierenga, Pioneers and Profits (Ames, 1968), 27, 108, 109, 120, 121. 
in the West was thus quickly snapped up to send back east to meet their obligations. The result, common for many developing economies, was a heavy burden of debt and a chronic shortage of specie. Such currency shortages decreased consumer demand, depressed sales, lowered prices, reduced incentives to produce or invest, and increased unemployment. Profits, land values, growth and development all stagnated, frustrating the ambitions of farmers, merchants, and bankers alike and making it even harder for them to pay off their debts.

Some town leaders advocated "fiscal" strategies such as import substitution, import boycotts, buy-at-home campaigns, and other tactics to reduce indebtedness. Bankers in many states sought more direct "monetary" solutions to the effects of currency shortages by simply issuing their own currency. Such "wildcat" currency was issued as legal tender which the bearer of the note could redeem in specie at the bank of issue. The currency was merely a substitute which preserved the specie in the vault for other purposes, such as loans. By accelerating local exchange, preserving specie, and allowing the bank to acquire more, while making a profit, notes initially seemed to be the answer to most of the problems resulting from indebtedness.

Soon after opening their bank in 1847, Cook and Sargent set out to find a way to pursue what might be called a local monetarist expansionary policy of banking despite the Iowa law forbidding banks in the state to issue their own currency. First they brought in outside money to circulate. Then in the early 1850 s they established a bank in Florence, Nebraska, from which they could issue notes through their "branch" bank in Davenport. With the support of John Burrows, Robert Prettyman, George Davenport, and, behind the scenes, Antoine LeClaire, they made an outlay of $\$ 100,000$ to issue $\$ 236,000$ worth of their currency. Buoyed by general economic good times between 1854 and 1856, the currency circulated freely and contributed to the town's vitality, apparently confirming expectations that it would in time develop into an entrepôt. ${ }^{29}$

29. Burrows, "Fifty Years," in Quaife, Early Day, 241-44. 


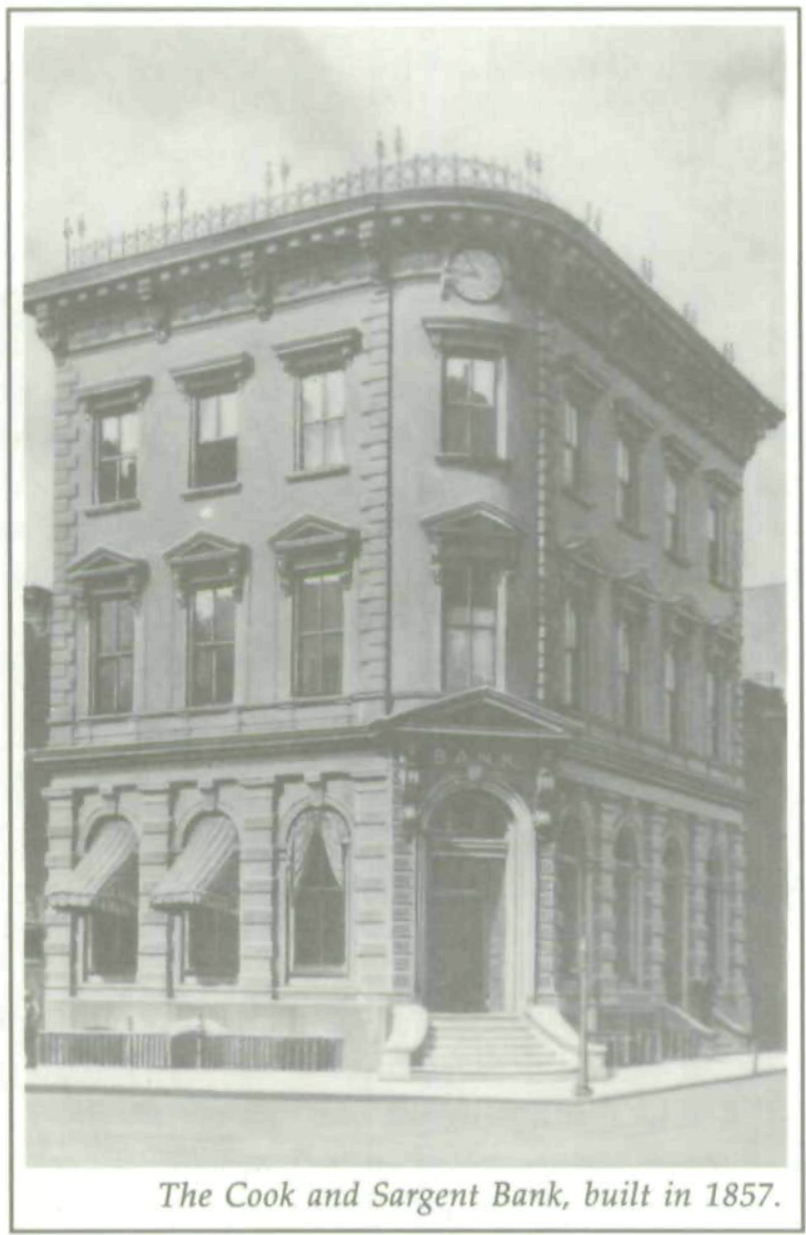

Inevitably, however, an excess of currency stimulated inflation, reducing its value and drawing its circulation back closer to home. By 1857 pressure on the currency had become acute, although the currency was strong enough to see Cook and Sargent through the bank panic of 1857. Difficulties began to arise when more than a few people tried to redeem notes for specie. To avoid paying out in specie, Cook and Sargent were forced to pay out in notes on other banks or in commercial debt paper redeemable at dependable merchants elsewhere in the Mississippi valley or back East. In doing so, they lost two primary means of acquiring more specie, which was necessary to support their own operations. Either way, the pressure of redeeming so many notes in circu- 
lation gradually wore down their reserves of notes, paper, and specie. ${ }^{30}$

In 1858 John Burrows stepped in to provide some relief. He issued his own checks, which Cook and Sargent offered at par in exchange for their currency. When the person who received Burrows's check presented it to Burrows, he then paid out in Cook and Sargent notes. This procedure allowed the bank some time to get ahead of the redemption pressure, to redeem their own notes on other banks, and to acquire others, so as to satisfy those customers presenting the bills. In time, however, even this strategy could not withstand the pressure. Several times in 1858 Cook and Sargent ended the business day with but a few dollars of commercial paper or specie in the bank..$^{31}$

At one time, Cook and Sargent's circulation had reached some $\$ 300,000$. By mid- 1858 they had retired $\$ 200,000$ of it, which they burned in the basement to ensure that it would not be sent back into circulation. Still the pressure continued. Eventually, Cook and Sargent stopped paying out Burrows's notes at par, an action Burrows still bitterly resented years later. Nevertheless, because the bank owed Burrows $\$ 100,000$, he was forced to continue to support it. ${ }^{32}$

Pressure emerged from another source in 1858 , when the Daily Democrat attacked the currency's inflationary effect on prices, rents, and the livelihood of Davenport's citizens, and urged people no longer to accept or deal in the currency. The same year, Austin Corbin, another local banker, announced he was no longer confident of receiving specie or commercial paper in return for Cook and Sargent notes. Then, after discounting the currency drastically, he declared that he would no longer accept it. ${ }^{33}$

These were critical developments. The notes were, in fact, simply loans from the bank. Much like loans, which can exceed by several times the deposits in a bank because it is unlikely that all depositors would want their money on any single day, the amount of currency issued could exceed the amount of spe-

30. Ibid., 259.

31. Ibid., 241-44, 252-59.

32. Ibid., 254-55, 258-60, 284-85, 287.

33. Ibid., $250-53$. 
cie backing it by several times. As long as people were confident that they could easily redeem the notes in their possession for gold and silver, the notes would be widely circulated at their face value. The exchange value of the notes was thus a direct reflection of a population's confidence in the soundness of the issuing bank and the integrity of the bankers. ${ }^{34}$

The dynamics of this local economic exchange reflected local patterns of social interaction, hierarchies, and values. The actions of the banker, like those of the merchant, reflected his "character." Public life was but a test of manhood. So, too, community social interaction rested on values of reciprocity, hierarchy, and honesty. A loan was more than an economic transaction. It was an expression of confidence and a test of honesty and responsibility. The web of loans, partnerships, and town currency mirrored the familial town community and its reciprocal web of social connections within a broader "harmony of interests." The soundness of local currency, then, reflected the soundness of the social body and the individuals within it-a parochial point of view challenged by the real dynamics of regional economic change..$^{35}$

With so much at stake, Cook and Sargent finally appealed to Antoine LeClaire for a note of endorsement on paper from back east. LeClaire provided the note, since the bank's existing debt to him linked their economic fates. LeClaire, out of selfinterest, agreed to give the bank a small, short-term loan, but he demanded a mortgage on the bank and the bankers' houses as collateral. Perhaps he realized that the bank was already doomed and felt he needed at least to try to save a bad investment while minimizing any further damage. In any case, LeClaire's attempted bailout was much too little too late. Caught several times with nothing in the bank against continuing demands for redemption, Cook and Sargent were forced to

34. William Bross, "Banking, Its History and Commercial and Social Importance," Peoria Weekly Republican, 30 April 1852.

35. Anthony F. C. Wallace, Rockdale: The Growth of an American Village in the Early Industrial Revolution (New York, 1978), 20-22, 394-96; Robert H. Wiebe, The Opening of American Society from the Adoption of the Constitution to the Eve of Disunion (New York, 1984), 281-83. 
suspend payments and close their doors on December 15, 1859. In spite of several promises to reopen, the bank never did. ${ }^{36}$

The outcome of this intricate financial strategy was the financial ruin of several key members of the elite. Several others of the cohort of 1845, even Antoine LeClaire, were severely damaged. As in other towns, one can be certain that the suffering extended beyond the big actors in the drama to encompass numerous other merchants from the LeClaire group as well as hundreds of townspeople and farmers who lost the value of notes held or deposits at the bank. Ultimately, however, the failure was a cohort failure, and it brought an end to its effective control of Davenport. Obsessed with maintaining and expanding a regionally oriented position, stretched out by investments in railroads and shifting relationships throughout the regional and national network, it seems, in the end, that Cook and Sargent simply let the situation get out of hand. Their actions took place as part of a euphoric period of speculation in which emotion rather than rational calculation ruled.

An even more basic cause of failure was the primary actors' failure to understand the changing dynamics of the regional context for their actions. The arrival of the railroad was a major cause of their confusion because it sent such mixed signals. But a more general lack of caution was nurtured by a parochial economic perspective. Members of the local elite assumed that local action could enable them to avoid the economic impact of the crash of 1857, a crisis that taught many other communities a hard lesson about the flow of power in national and regional systems. Ironically, as the situation worsened, Davenport's elite, too, began to turn to the system for help, and used it to displace blame. When George Sargent needed commercial paper to continue operating in 1858, he left for Boston to open a branch and to take some of the pressure off the local effort to acquire such paper. Likewise, when townspeople rushed the houses of the mayor and John Burrows in the currency riot of late summer 1859, demanding an explanation of

36. Burrows, "Fifty Years," in Quaife, Early Day, 250, 259-60, 276-83, 28486; Erling A. Erickson, Banking in Frontier Iowa, 1836-1865 (Ames, 1971), 50-55, 57, 64-65; August Richter, "A True History of Scott County," Davenport Democrat and Daily News, 17, 19 December 1859, 9, 22 January 1860. 
rumors about the legitimacy of the currency scheme, he and others pointed the finger of blame elsewhere: on city government, on the system, on outsiders. There was, in short, little that local people could do. The course of events had been taken out of their hands. Regional concerns, and the concerns of individuals to respond to this regionally oriented disaster, overwhelmed local interaction and the sense of community it had previously produced. ${ }^{37}$

Finally, when the bank failed, those most deeply implicated felt unable to continue to live in the town. George Sargent left his magnificent mansion in hock to Antoine LeClaire and left town to work for the Northern Pacific Railroad at Durant, Iowa, and Duluth, Minnesota, before landing a job as a stock salesman for the railroad back east and in Europe. Ebenezer Cook landed a job as a manager for the Rock Island Railroad before he died in 1871. Austin Corbin went east to restart his career as a financier. Ambrose C. Fulton moved to Chicago. John Dillon went east for several years. Several others also left for jobs elsewhere. John Burrows never really recovered; he spent the next twenty years scraping a living from a variety of odd jobs. Even Antoine LeClaire never succeeded in fully restoring his tarnished reputation; after all, he meant less to newcomers and had less power now that his cohort had been brought down. His death in 1861, accompanied by the vacuum in local leadership, the shift of railhead functions to the west, and the gradual decline of the lumber business, marked the end of an era in the city's history. The impressive Victorian funeral march in his honor, with the town's early settlers marching behind the casket through the streets of Davenport, was a symbolic funeral for their leadership and the localist assumptions by which they ruled. ${ }^{38}$

37. Scott County, Iowa, Tax Lists, 1858, 1860; Burrows, "Fifty Years," in Quaife, Early Day, 250-53, 273-75.

38. Earle D. Ross, "George Barnard Sargent," 129-32; Obituary for Mrs. George Sargent, Davenport Democrat, 15 March 1896; Obituary for Ebenezer Cook, Davenport Democrat, 7 October 1871; Inventory of the Estate of Ebenezer Cook, 1871, Office of the County Clerk, Scott County Courthouse, Davenport; Burrows, "Fifty Years," in Quaife, Early Day, 284-86; Richter, "True History of Scott County"; History of Scott County, 609-10; Richter, Geschichte der stadt Davenport und des county Scott, 89-90. 
THE EVIDENCE from the social history of Davenport before the Civil War suggests a number of general observations concerning the interplay between local and regional social strategies and actions. The course and relative balance of this interplay varied with the frequency of town and regional interactions. During periods of slow growth, confident prosperity, and stable regional functional arrangements, or even relative stagnation or decline, local elites might tend to focus their energies on consolidating local social control and clarifying local social arrangements or structures. During such periods the elite, or any other social group in town, would assume that social change in town paralleled that elsewhere and that its meaning was defined on its own terms. But during periods of rapid growth, changing function, or economic crisis, when newcomers flooded town or townspeople left in droves for other opportunities, the structure of local society could be overwhelmed or undermined, invalidating local assumptions and making local concerns seem trivial in comparison to the more urgent need to maintain the town society's position in the regional system. When the survival of the town was at stake, local elites would focus their energy on accepting, screening, placating, compromising with, or even rejecting or resisting newcomers. Likewise, they might breech local social etiquette by encouraging, or helping, in order to dissuade, those ready to leave for other towns.

Further afield, local elites might rethink the state of their interactions with others across the system, and thus begin to formulate regional social strategies with the goal of redefining themselves in a regional context. Merely deciding that they needed to reestablish contacts with acquaintances or friends in another city would be an example of such a strategy. In the former case, their education in social self-awareness occurred right at home; in the latter case, it tended to occur across the region. But in both situations the local group acquired deeper selfknowledge, developed a new self-image, and formulated new strategies of action and behavior on the basis of that new image. In either case, these strategies could, given the circumstances, lead to positive or negative consequences.

The simplest regionally oriented strategy encountered locally was to accept newcomers and actively assimilate them 
into the local social structure. A less receptive strategy would be to establish a screening process that newcomers must go through before their regional credentials could be translated into local reality, and hence accepted. A resistant strategy would simply seek to keep the doors to local society closed no matter what stress it was under. By limiting entrance to local society, the local social elite would thus restrict their interaction with regional society and, they hoped, continue to exert control in a situation according to the criteria they had established.

On the one hand, therefore, one could negotiate with others in the system and reorient local society to the broader, more generalized, impersonal criteria of a regional society, usually centered at the metropolis. On the other hand, one could simply retreat from regional society, isolate town society, and hope that locals would not mind the social implosion caused by such a strategy. Although this strategy often resulted in local society falling behind the times, it did not always threaten local survival or power.

Some strategies tended to unify and alter the nature of group and class interaction in town in a positive way; others tended to individualize town society, encouraging individuals to break free from the restraints of group and class control and act in their own best self-interest. In such an atmosphere, whatever collective strategies had been undertaken for the collective improvement of the town would, of course, dissolve. Encasing the internal linear process of social development in any town, therefore, was this web of interactions between locals and outsiders, occurring both at home and across the system. These interactions also provided the local process of social development and the local social structure with a broader, more impersonal, and hence probably their real meaning.

That meaning came through clearly when, in the mid1850 s, the citizens of Davenport embraced the railroads, only to find out that the railroads did not care much for local concerns, and that locals could do little to alter the priorities of the Chicago decision makers. For a while in the late 1860s Davenport joined other river towns with rail connections to the West as an entrepôt for wood shipments from Minnesota and Wisconsin, although Dubuque and Burlington seemed to benefit more 
from that trade ${ }^{39}$ Gradually the town slipped into an economic eddy in the new system, providing local trade and manufacturing, growing only slightly until after 1890 . It had become a provincial outpost almost before the townspeople were aware that it had happened.

At each stage of Davenport's early history, its people were compelled to confront regional reality and formulate strategies to get the better of it. Early on these strategies were informed by a desire to recreate a complete local economy and society in their town. Davenport would become, in their view, a microcosm, a recreation of economies and societies elsewhere. Their community would, they hoped, operate according to the "values of the town" in which a "harmony of interests" ruled. That would enable them to act independently in the broader system..$^{40}$ But when the intense interaction with the system disrupted the process of local development and began to shape a peculiar, discontinuously constructed economic and social milieu, a sense of declining control and order set in. And when, after 1858 , the entire society was pushed on its side by the dictates of the new regional system, and everyone in town reoriented their concerns from supporting local reality to surviving amid the new regional one, the character of local life was altered forever.

Local analysis that seeks only to discover the nature of community, the interaction of classes, and the character of social control, will, like the assumptions of early townspeople, only reinforce the false image of continuous communities and lead to historical dead ends. It was the actions of the townspeople in the regional sphere that mattered. Their responses to change in the outside world and the way they translated those responses into local reality were at the center of their historical experience. That dynamic was also the primary means of creating a distinctive local reality. That historical effort continues today. Only the assumptions, goals, and expectations are different.

39. Agnes M. Larson, A History of the White Pine Industry in Minnesota (Minneapolis, 1949), 105, 107, 122, 125.

40. Wiebe, The Opening of American Society, 184. 
Copyright of Annals of Iowa is the property of State of Iowa, by \& through the State Historical Society of Iowa and its content may not be copied or emailed to multiple sites or posted to a listserv without the copyright holder's express written permission. However, users may print, download, or email articles for individual use. 